\title{
Cadmium: An Emerging Role in Adipose Tissue Dysfunction
}

\author{
Sarra Mohammed Attia ${ }^{1,2}$ - Kavitha Varadharajan ${ }^{1}$ (D) Muralitharan Shanmugakonar ${ }^{1}$ (1) \\ Sandra Concepcion Das ${ }^{1}\left[\right.$ [ Hamda A. Al-Naemi ${ }^{1,2}$ (])
}

Received: 29 April 2021 / Revised: 27 July 2021 / Accepted: 18 August 2021 / Published online: 10 September 2021

(c) The Author(s) 2021

\begin{abstract}
Cadmium $(\mathrm{Cd})$ is a toxic heavy metal that is widespread in the environment due to the substantial anthropogenic inputs from the agriculture and industrial sectors. The toxic impact of $\mathrm{Cd}$ adversely affects human health and is linked with endocrine disruption, carcinogenicity, diabetes-related diseases, and metabolic disorder. One of the main characterizations of $\mathrm{Cd}$ is bioaccumulation where its half-life reaches 40 years with an unknown biological role. Several organs were found to be targets for $\mathrm{Cd}$ accumulation such as the liver, kidneys, and adipose tissue. Adipose tissue (AT) is a dynamic organ that plays a significant role in the body's homeostasis through the maintenance of energy storage. Another vital function for AT is the secretion of adipokines which provides a metabolic cross-talk with the whole body's organs. Cd is found to adversely impact the function of AT. This includes the disruption of adipogenesis, lipogenesis, and lipolysis. As a consequence, dysfunctional AT has disruptive patterns of adipokines secretions. The main adipokines produced from AT are leptin and adiponectin. Both were found to be significantly declined under the $\mathrm{Cd}$ exposure. Additionally, adipose tissue macrophages can produce either anti-inflammatory markers or pro-inflammatory markers depending on the local AT condition. Cadmium exposure was reported to upregulate pro-inflammatory markers and downregulate anti-inflammatory markers. However, the exact mechanisms of Cd's adverse role on AT structure, function, and secretion patterns of adipokines are not totally clarified. Therefore, in this review, we present the current findings related to $\mathrm{Cd}$ detrimental effects on adipose tissues.
\end{abstract}

Keywords Cadmium $\cdot$ Environmental toxicants $\cdot$ Heavy metals $\cdot$ Adipose tissue $\cdot$ Adipocyte dysfunction $\cdot$ Metabolic disorder

\section{Introduction}

Rapid urbanization and intensive industrialization have caused an increase in the contamination level of environmental toxicants. The sector of environmental toxicants is very diverse which includes but are not limited to organic and inorganic chemicals, xenobiotics, pesticides, and heavy metals (Bhunia 2017). Over the past years, environmental toxicants gained more attention from researchers due to the adverse effects on the health of living organisms. Heavy metals are environmental toxicants that can be found naturally in the Earth's crust. Thus, weathering of metal rocks,

Hamda A. Al-Naemi

halnaemi@qu.edu.qa

1 Laboratory Animal Research Center, Qatar University, Al Tarfa St., P.O Box 2713, Doha, Qatar

2 Department of Biological and Environmental Science, Qatar University, Doha, Qatar volcanic eruption, atmospheric deposition, and leaching into soil and groundwater are natural sources of heavy metals (Cimboláková et al. 2020). While fertilizer usage, irrigation, industrial emission, fossil fuel combustion, smelting, and mining are the main anthropogenic sources of heavy metals contamination (Violante et al. 2010). The increased contamination level of heavy metals is associated with high rates of their transportation and mobilization caused by heavy industrial inputs (Baran and Tarnawski 2015; Xie et al. 2019).

One of the main hazardous heavy metals is cadmium $(\mathrm{Cd})$ that is widespread in the environment and listed the seventh rank in the priority list of toxic pollutants by the Agency for Toxic Substances and Disease Registry (ATSDR 2019). Among the scientific community Cd toxicity is well documented and its toxic impact includes endocrine disruption, carcinogenicity, diabetes-related diseases, and metabolic disorder (Garcia-Morales et al. 1994; Iavicoli et al. 2009; Matović et al. 2011; Jiménez-Ortega et al. 2012; Han et al. 2015; Tinkov et al. 2017; Nasiadek et al. 2018; Lauretta 
et al. 2019; Cimboláková et al. 2020; Buha et al. 2020). Cadmium has no biological role in the body and its excretion from the body is very slow since the estimated half-life, in humans, is about 40 years (Tucker 2011; Young et al. 2019). Cadmium-contaminated food and water in addition to smoking are the main routes of Cd exposure (Fatima et al. 2019). For example, the usage of fertilizers that contain $\mathrm{Cd}$ and $\mathrm{Cd}$-contaminated water in agriculture are the main attributes that cause terrestrial food to be exposed to Cd (Ali et al. 2019; Sabir et al. 2019). Common types of food such as cereals, bread, leafy vegetables, nuts, wild mushrooms, rice, and cocoa powder are potential sources of Cd contamination (COWI A/S 2003; Tchounwou et al. 2012; Kim et al. 2018). Moreover, $\mathrm{Cd}$ is among the most accumulated metals in the soil which impacts not only food plants but also the groundwater, especially in the areas of active anthropogenic inputs (Xie et al. 2019; Luo et al. 2020). Besides terrestrial food, aquatic food is also a major source of $\mathrm{Cd}$ exposure. Cadmium is found to be distributed within the particulate matter and the sediments which are the main sources of $\mathrm{Cd}$ exposure for the aquatic organisms (Kay 1985). As a consequence, the elevated $\mathrm{Cd}$ level in the marine environment has undesirable effects on marine animals since they are susceptible to Cd bioaccumulation (Dallinger et al. 1987; COWI A/S 2003; Safety 2011; Chunhabundit 2016). Food is a major source of the body's nutrition and energy, thus when consuming Cd-contaminated food, vital biological processes may get affected.

The ingested Cd targets several major organs in the body including the liver and kidneys which primarily exhibit high rate of $\mathrm{Cd}$ accumulation rates (Jacobo-Estrada et al. 2017; Genchi et al. 2020). In addition to that, it has been recently found that $\mathrm{Cd}$ also accumulates in adipose tissue which opens a door for more research. Adipose tissue (AT) is known as an energy reservoir and endocrine organ that contributes actively to systemic energy homeostasis (Prins 2002; Coelho et al. 2013). It secretes adipokines or hormones and cytokines that act in paracrine, autocrine, and endocrine manners (Funahashi et al. 2004; Akingbemi 2013; Stansfield et al. 2014). Besides the secretion function, AT cross-talks and regulates other body organs, metabolism, immunity, reproduction, and cardiovascular functions (Coelho et al. 2013; Kwon and Pessin 2013). Accordingly, the endocrine function of AT is regulated significantly by the nutritional status that is linked to the role of AT in energy storage (Prins 2002; Kwon and Pessin 2013). The main adipokines produced by AT are adiponectin and leptin with multiple roles such as regulation of inflammation and energy homeostasis (Fantuzzi 2005). Several studies reported that metal toxicity including $\mathrm{Cd}$ negatively affects adipokine secretion (Levy et al. 2000; Kawakami et al. 2012; CejaGalicia et al. 2017; Renu et al. 2018; Rizzetti et al. 2019; Wang et al. 2021). As a consequence, metabolic disruption, local and systemic inflammation may induce and antagonize the body's homeostasis. These contributions suggest that AT is more complex than initially thought with multiple unique features.

The dynamic nature of the AT can be reflected by the different types of AT (i.e. white, brown, and beige) and its heterogeneity which provides the adaptive capacity under different physiological conditions. In the toxicological context, white adipose tissue has the feature of sequestering harmful toxicants and pollutants to limit its impact on other organs (Mustieles and Arrebola 2020). Thus, AT provides an advantageous role in assessing toxicants' acute and chronic exposure effects and helps investigate early markers for chronic diseases such as metabolic syndrome or diabetes mellitus. This review aims to present an overview of the potential effects of $\mathrm{Cd}$ exposure on AT function and summarize the detrimental result of these effects.

\section{Adipose Tissue and Cadmium Bioaccumulation}

Adipose tissue is classified into two types: white adipose tissue and brown adipose tissue. Their distribution throughout the body is determined by several factors such as nutritional status and environmental temperature (Fantuzzi and Braunschweig 2014). For this review, white adipose tissue (WAT) will be the main focus and will be discussed in detail. White adipose tissue comprises the largest part of AT and it is known for its critical role in energy storage, insulin sensitivity, and endocrine communication (Fantuzzi 2005; Frühbeck and Gómez-Ambrosi 2013; Choe et al. 2016). Morphologically, WAT has unilocular adipocytes that contain a large central lipid droplet besides the nucleus and mitochondria (Richard et al. 2000; Frühbeck and Gómez-Ambrosi 2013). Also, it is composed of special loose connective tissue that contains different cell types including adipocytes, stromal vascular fraction, blood vessels, preadipocytes, fibroblasts, and lymph nodes that include immune cell types (Frühbeck and Gómez-Ambrosi 2013; Henriques et al. 2019). This special structure allows AT to function as a storage reservoir, endocrine organ, and cushion for internal organs. Moreover, regional fat distribution throughout the body is associated with several inner organs such as the liver, kidney, and heart which could be used as an indicator for various metabolic alterations (Frühbeck and Gómez-Ambrosi 2013).

Adipose tissue regulates long-term storage and excess energy accumulation and releases through lipogenesis and lipolysis (Booth et al. 2016). These processes are highly dependent on hormonal, metabolic, and nutritional factors determined by the body's demands and health status (Fantuzzi and Braunschweig 2014). Under physiological conditions, the triglycerides (TGs) are synthesized from 
excess carbohydrates or lipids as a form of energy stored via lipogenesis as summarized in (Fig. 1). To meet the energy demand of the body, TGs are released via lipolysis and generates glycerol and FFAs from TGs with the help of hormone-sensitive lipase (HSL) (Richard et al. 2000; Fantuzzi and Braunschweig 2014; Vegiopoulos et al. 2017).

In addition to storage, AT secretes and produces hormones known as adipokines that have endocrine and paracrine effects. They target different organs including the AT itself, liver, brain, vessels, bones, and muscles (Ouchi et al. 2011; Fasshauer and Blüher 2015; Freitas Lima et al. 2015; Francisco et al. 2017). These adipokines include adiponectin, leptin, resistin, tumor necrosis factor-alpha (TNF- $\alpha$ ), interleukin 6 (IL-6), monocyte chemotactic protein-1 (MCP1 ), and others. Thus, they play functional roles in appetitesatiety balance, glucose tolerance, energy expenditure, insulin resistance sensitivity, and both local and systemic inflammation (Fantuzzi 2005; Booth et al. 2016; Mancuso 2016; Stern et al. 2016).

The secretory status of the AT depends on the changes of the cellular composition including structure, number, and the depot site alterations (Ouchi et al. 2011). Changes in adipose cell numbers (hyperplasia), shape, or size (hypertrophy) are hallmarks of AT dysfunction (Pellegrinelli et al. 2016). Lipodystrophy and fat loss occur either due to decreased adipocyte number or declined adipocyte size (Kahn et al. 2019). These changes are linked with abnormal secretion of adipokines, systemic and local inflammatory conditions. As well as several metabolic processes such as glucose intolerance, insulin resistance, and hyperlipidemia (Choe et al. 2016; Schoettl et al. 2018; Henriques et al. 2019; Recinella et al. 2020).

Adipose tissue is found to be a target of $\mathrm{Cd}$ accumulation. Exposure to $\mathrm{Cd}$ can occur through inhalation of smoke

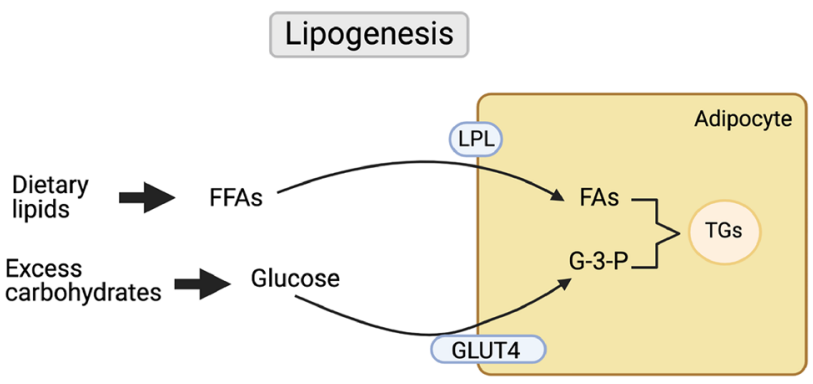

Fig. 1 Overview of lipogenesis in AT Triglycerides (TGs) are synthesized from excess carbohydrates or lipids as a form of energy stored in AT. Lipogenesis in AT can be divided into three steps. First, dietary lipids are taken up from the circulation in the form of free fatty acids (FFAs) with the help of lipoprotein lipase (LPL). Second, glucose is taken up with the aid of GLUT4 and converted to glycerol (G-3-P) by adipocytes to help in the esterification of fatty acids (FAs). Finally, the FAs are esterified into triglycerides. (Created using BioRender.com) and food ingestion. After Cd enters the body, it binds to albumin and erythrocytes in the blood and migrates into the body's organs and tissues (Tchounwou et al. 2012; Fatima et al. 2019; Tinkov et al. 2021). The main mechanism of $\mathrm{Cd}$ transportation and accumulation is facilitated by metallothionein (MT) protein. The binding affinity between MT and metal ions was found to be the highest with $\mathrm{Cd}$ due to the presence of the thiol group (-SH); MT can concentrate up to 3.000-fold (Patrick 2003; Genchi et al. 2020). One of the main targets of $\mathrm{Cd}$ is the liver, where MT is primarily produced. Then, Cd-MT complexes are released from the liver into the kidney and transferred to other tissues (Patrick 2003). Several studies measured Cd levels under different exposure conditions (acute, chronic, low dose, and high dose) and reported that tissues of the liver and kidneys are the main targets for $\mathrm{Cd}$ accumulation and toxicity (Toman et al. 2009; Lech and Sadlik 2017; Borowska et al. 2017; Fay et al. 2018). However, AT is known to be the main reservoir of lipophilic toxicants which can form lipophilic complex with heavy metals including Cd (Lauretta et al. 2019).

In 2010, Kawakami et al. used adult male mice to investigate the accumulation of repeated $\mathrm{Cd}$ doses of $0,5,10$ and $20 \mu \mathrm{mol} / \mathrm{kg}$ body weight in AT. They reported that $\mathrm{Cd}$ accumulation occurs in a dose-dependent response. At the highest dose $(20 \mu \mathrm{mol} / \mathrm{kg})$, the Cd concentration in AT was $0.404 \mu \mathrm{g} / \mathrm{kg}$ and at the lowest dose $(5 \mu \mathrm{mol} / \mathrm{kg}) \mathrm{Cd}$ concentration was $0.114 \mu \mathrm{g} / \mathrm{kg}$. On the other hand, Echeverría et al. (2019) explored the $\mathrm{Cd}$ accumulation in AT of adult humans. Their study reported that $\mathrm{Cd}$ in AT had a mean concentration of $12.66 \mu \mathrm{g} / \mathrm{kg}$ body weight. Certain parameters were found to be correlated with high Cd concentration in AT such as smoking, age, body mass index, and the types of food consumed (Echeverría et al. 2019). Moreover, a recent study examined $\mathrm{Cd}$ accumulation in the human body and reported that Cd accumulates in AT (Egger et al. 2019). Their findings reported median $\mathrm{Cd}$ concentrations of 32 and $42 \mu \mathrm{g} / \mathrm{kg}$ in breast adipose tissue and waist adipose tissue, respectively. This suggests that AT has the potential to be the biggest $\mathrm{Cd}$ pool since it occupies a large part of the body. To the best of our knowledge, the exact mechanism of $\mathrm{Cd}$ accumulation in AT is not yet fully understood.

\section{Cadmium and Adipose Tissue Dysfunction}

The alterations of AT structure and its cellular composition lead to the impairment of its normal physiological functions such as energy imbalance, abnormal secretions, and immune cell infiltration (Trim et al. 2018). Adipose tissue is known for its plasticity that makes it adaptive to accumulate the surplus of energy in the form of triglycerides (Badimon and Cubedo 2017; Martínez-Fernández et al. 2018). However, under metal toxicity, AT function can be disrupted and 
linked to the development of metabolic disorders (Planchart et al. 2018; Gao et al. 2019; Rizzetti et al. 2019).

Adipogenesis is an essential process that includes the maturation of preadipocyte to adipocyte. The healthy growth of adipocytes is related to nutritional intake and energy storage demand with features of well-vascularized adipocyte and minimal degree of inflammation (Vishvanath and Gupta 2019; Orsso et al. 2020). Adipogenic key markers for AT differentiation are CCAAT/enhancer-binding protein $(\mathrm{C} /$ EBP) and Peroxisome proliferator-activated receptor-gamma (PPAR- $\gamma$ ). Adipose tissue dysfunction is associated with disruption of adipogenesis and impairment of adipocytes differentiation capacity. In this context, a toxicological study claimed that Cd-treated WAT exhibited a pattern of reduction in the expression level of both C/EBP and PPAR- $\gamma$ (Kawakami et al. 2010). This also is in accordance with another study, which reported that $\mathrm{Cd}$ exposure significantly decreased the mRNA expression level of PPAR- $\gamma$ in Cdtreated WAT (Kawakami et al. 2013). Moreover, differentiation of 3T3-L1 preadipocytes found to be inhibited by $\mathrm{Cd}$ through the suppression of expression level of both $\mathrm{C} /$ EBP and PPAR- $\gamma$ (Lee et al. 2012). Taken together, these data suggest that $\mathrm{Cd}$ influences adipogenesis which disturbs both processes of lipid accumulation and adipocytes growth (Fig. 2). This adversely affects the main storage function of AT, and consequently, metabolic processes and systemic signaling.

In line with that, histopathological studies demonstrated the effects of Cd on AT. Kawakami et al. (2010) reported a significant decrease in mice AT weight and adipocytes size after $\mathrm{Cd}$ treatment in a dose-dependent manner. More exploration was done by the same team, to study the effect of acute Cd exposure in MT- null mice and found that, adipocytes size was significantly reduced (Kawakami et al. 2013). In agreement with these results, a recent study reported that mice exposed to $\mathrm{Cd}$ for 8 weeks exhibited a significant reduction in both body weight and adipocytes size (Prabhu et al. 2020). However, an earlier study that examined the Cd effect on AT using a rat model, reported no changes in both body weight and adipocyte size (Ficková et al. 2003). Similarly, Treviño et al (2015) reported that $\mathrm{Cd}$ administration of 120 days neither had an impact on rats' body weight nor the AT size. It is worth noting that studies that explored $\mathrm{Cd}$ effect using rat models reported no changes in both body weight and adipocyte size. However, other parameters were found to be adversely affected such as circulating lipid profile and insulin receptors (Table 1). From the above, we can conclude that $\mathrm{Cd}$ at different exposure conditions has the potential to induce a toxic impact on AT main storage function. This impact can be observed as an impairment of gene expression of adipogenesis markers (C/EBP and PPAR- $\gamma$ ), circulating lipid profile, and AT structure that provide the required

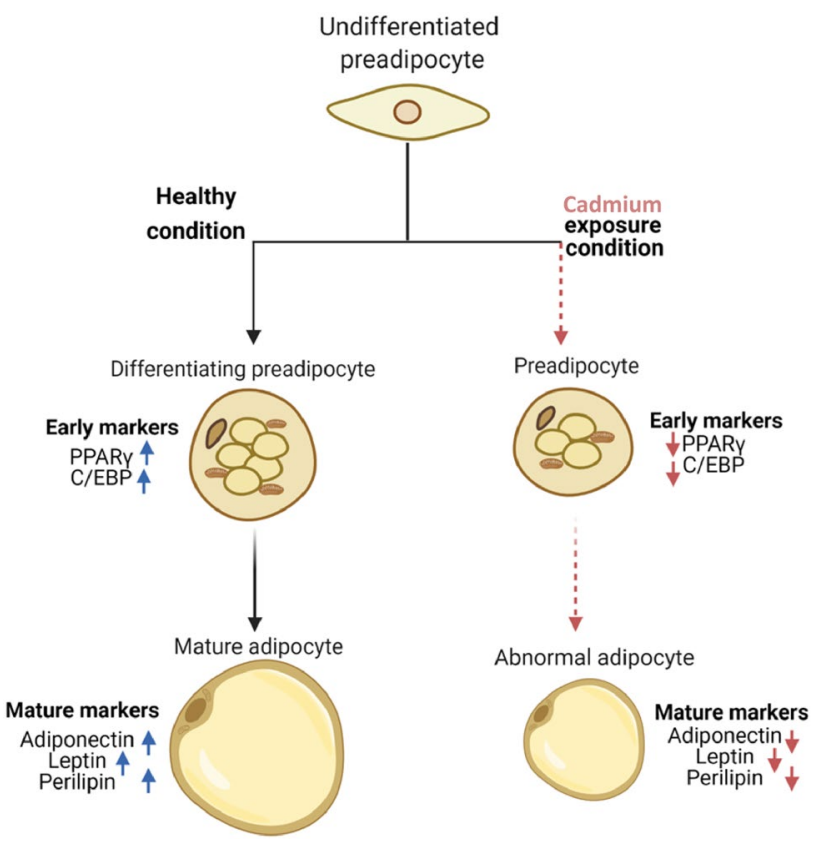

Fig. 2 Overview of Cd adverse effects on adipogenesis When preadipocytes reach the commitment phase before differentiation, it activates the key regulators of adipogenesis PPAR- $\gamma$ and C/EBPa and $\beta$ at the early stage of differentiation. While at the late stage of differentiation, mature adipocytes express a couple of markers such as: leptin, adiponectin and perilipin besides the early markers. Under Cd exposure, the key regulators in the early stage exhibit pattern of reduction in their expression which adversely affects the process of lipid accumulation, rate of adipocytes differentiation and the expression level of maturation markers. Consequently, decrease in the size of adipocyte. (Created using BioRender.com)

functional capacity and plasticity features of AT. Although the above-listed studies explored the effect of $\mathrm{Cd}$ on AT structure but, there is a lack of consistency with the outcomes due to differences in dose, duration, speices and experimental design. Moreover, histopathological research is needed to provide a better understanding of exact AT structural changes and the involved mechanisms under different $\mathrm{Cd}$ exposure conditions.

The structural changes resulted from Cd toxicity are associated with the presence of local inflammation in AT and are marked by several inflammatory and adipokines secretions besides leukocyte infiltration (Booth et al. 2016; Greevenbroek et al. 2016; Kahn et al. 2019). Taking into consideration the wide distribution of the AT throughout the body, the changes in AT microenvironment may play a role in the systemic inflammation as well (Martínez-Fernández et al. 2018). To evaluate the impact of Cd on AT dysfunction, adipokines expression levels are measured as indicators of inflammation and metabolic disorder (Frühbeck and GómezAmbrosi 2013; Fasshauer and Blüher 2015; Freitas Lima et al. 2015; Unamuno et al. 2018). The main adipokines 
Table 1 The effect of different Cd exposure conditions on AT function and structure

\begin{tabular}{|c|c|c|c|c|}
\hline Model & Dose and duration & Exposure method & Observations & References \\
\hline Male wister rats & $9.7 \mathrm{mg} / \mathrm{l}$ to 6 weeks & Dissolved in drinking water & $\begin{array}{l}\text { Adipocytes size: } \leftrightarrow \\
\text { Body weight: } \leftrightarrow \\
\text { AT insulin receptor: } \downarrow\end{array}$ & Ficková et al. (2003) \\
\hline Male Sprague-Dawley rats & $2 \mathrm{mg} / \mathrm{kg}$ to 4 days & Subcutaneous injection & $\begin{array}{l}\text { Body weight: } \leftrightarrow \text { GLUT4 } \\
\text { expression in AT: } \downarrow\end{array}$ & Han et al. (2003) \\
\hline Male Slc:ICR mice & $\begin{array}{l}0,10,20 \text {, and } 30 \mathrm{molCd} / \mathrm{kg} \\
\text { bw to } \\
2 \text { weeks }\end{array}$ & Subcutaneous injection & $\begin{array}{l}\text { Body weight: } \\
\text { - at low doses: } \leftrightarrow \\
\text { - at high doses: } \downarrow \\
\text { WAT weight: } \\
\text { - at high doses: } \downarrow \\
\text { Adipocytes size: } \\
\text { - at high doses: } \downarrow \\
\text { Adipose PPAR } \gamma 2 \text { expres- } \\
\text { sion: } \downarrow \\
\text { Adipose C/EBP } \alpha \text { expres- } \\
\text { sion: } \downarrow \\
\text { Adiponectin expression: } \downarrow\end{array}$ & Kawakami et al. (2010) \\
\hline Male wister rats & $\begin{array}{l}50 \text { and } 100 \mathrm{ppm} \mathrm{Cd} \text { to } \\
7 \text { weeks }\end{array}$ & Dissolved in drinking water & $\begin{array}{l}\text { Plasma TGs: } \uparrow \\
\text { Plasma LDL + VLDL: } \uparrow\end{array}$ & Afolabi et al. (2012) \\
\hline MT-null mice & $\begin{array}{l}0,0.5 \text { and } 0.75 \mathrm{mg} \mathrm{Cd} / \mathrm{kg} \\
\text { bw to } \\
7 \text { days }\end{array}$ & Subcutaneous injection & $\begin{array}{l}\text { Body weight: } \\
\text { - at higher dose: } \downarrow \\
\text { WAT weight: } \\
\text { - at higher dose: } \downarrow \\
\text { Adipose PPAR } \gamma 2 \text { expres- } \\
\text { sion: } \downarrow \\
\text { Adipose C/EBP } \alpha \text { expres- } \\
\text { sion: } \downarrow \\
\text { WAT macrophages: } \uparrow \\
\text { WAT MCP- } 1 \text { expression: } \uparrow \\
\text { Leptin expression: } \downarrow \\
\text { Perilipin expression: } \downarrow\end{array}$ & Kawakami et al. (2013) \\
\hline Male wister rats & $\begin{array}{l}32.5 \text { ppm } \mathrm{Cd} \text { to } 60,90 \text { and } \\
120 \text { days }\end{array}$ & Dissolved in drinking water & $\begin{array}{l}\text { Body weight: } \leftrightarrow \\
\text { Adipocytes size: } \leftrightarrow \\
\text { Circulating FFAs, TGs, LDL } \\
\text { and VLDL: } \uparrow\end{array}$ & Treviño et al. (2015) \\
\hline ICR mice & $100 \mathrm{ppm} \mathrm{CdCl}_{2}$ to 8 weeks & Dissolved in drinking water & $\begin{array}{l}\text { Body weight: } \downarrow \\
\text { Adipocytes size: } \downarrow\end{array}$ & Prabhu et al. (2020) \\
\hline
\end{tabular}

Arrows indication: $\uparrow$ increasing, $\downarrow$ decreasing, $\leftrightarrow$ no change

namely adiponectin and leptin, and their interaction with IL-6, TNF- $\alpha$, MCP-1 will be discussed further below.

\section{Cadmium and Adiponectin}

Adiponectin is a hormone produced and secreted mainly by adipocytes with anti-inflammatory, anti-apoptotic, and insulin-sensitizing effects (Fasshauer and Blüher 2015; Achari and Jain 2017; Tumminia et al. 2019). The level of adiponectin in the circulation has a positive correlation with HDL cholesterol and a negative correlation with inflammatory markers (Krakoff et al. 2003; Novotny et al. 2012; Frühbeck et al. 2017). Thus, adiponectin downregulation and pro-inflammatory molecules upregulation leads to homeostasis disturbance and promote metabolic dysfunction (Yamauchi et al. 2007; Murdolo et al. 2013; Upadhyaya et al.
2014; Tumminia et al. 2019). The anti-inflammatory role of adiponectin was demonstrated when adiponectin-knockout mice developed an inflammatory response (Mancuso 2016). This role is achieved by promoting the polarization of macrophages towards anti-inflammatory phenotype (Mandal et al. 2011). Moreover, in adipocytes, adiponectin enhances both healthy expansion and lipid storage and prevents the risk of ectopic fat accumulation where TGs are stored outside the AT (Stern et al. 2016). Few studies investigated the $\mathrm{Cd}$ effect on adiponectin expression and reported that the mRNA expression level of adiponectin in AT had a significant decrease under $\mathrm{Cd}$ acute exposure condition (Kawakami et al. 2010). Furthermore, in MT-null mice, exposure to different $\mathrm{Cd}$ doses $(5,10$, and $20 \mu \mathrm{M})$, significantly decreased adiponectin expression level (Kawakami et al. 2013). These results are consistent with data collected from in vivo studies 
after treatment with arsenic and mercury exposure (Rizzetti et al. 2019; Farkhondeh et al. 2019). These changes in adiponectin under unhealthy conditions, make its low expression a potential marker for AT dysfunction.

Adiponectin and TNF- $\alpha$ has a similar globular domain but different sequences and they exhibit opposite effects (Fantuzzi 2005). It was demonstrated that adiponectin knockout mice expressed a high mRNA level of TNF- $\alpha$ in AT and a high level of TNF protein in the blood (Maeda et al. 2002; Ouchi et al. 2011). Interestingly, when these mice were treated with adiponectin, TNF- $\alpha$ levels were restored within the normal range. Hence, in the case of inflammation, the pattern of TNF- $\alpha$ upregulation and adiponectin downregulation are quite common (Novotny et al. 2012).

Another pro-inflammatory adipokine is the IL-6 which has cross-talk with adiponectin as well. The production of adiponectin could be inhibited by IL- 6 (White and Stephens 2011; Upadhyaya et al. 2014). One of the suggested mechanisms of IL-6 action on adiponectin is through the activation

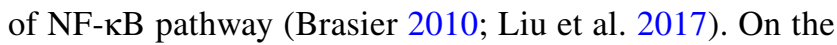
other hand, the anti-inflammatory activity of adiponectin inhibits the production of IL- 6 by the induction of interleukin 10 (IL-10) which is an anti-inflammatory cytokine (Mancuso 2016). Thus, the upregulation of IL-6 along with downregulation of adiponectin leads to insulin signaling impairment which promotes metabolic dysfunction (Murdolo et al. 2013).

The activity of adiponectin is mediated through its two receptors: adiponectin receptor 1 (Adipo-R1) and adiponectin receptor 2 (Adipo-R2) (Ye and Scherer 2013). Adipo$\mathrm{R} 1$ is widely expressed in muscle and Adipo-R2 is mainly expressed in the liver and both help regulating glucose metabolism and insulin sensitivity (Ceddia et al. 2005; Francisco et al. 2017). Adiponectin modulates the activation of AMP Kinase and activates PPARs which enhance glucose uptake and oxidation of fatty acids (Sharma et al. 2016). Several findings showed that Cd activates NF- $\kappa B$ pathway which leads to the upregulation of pro-inflammatory cytokines such as IL- 6 and TNF- $\alpha$ (Freitas and Fernandes 2011; Zhang et al. 2016, 2021; Hossein-Khannazer et al. 2020). The upregulation of Il- 6 and TNF- $\alpha$ was found to be adversely affects both PPAR $\gamma$ and adiponectin activities (Ye 2008; Upadhyaya et al. 2014). As mentioned earlier, adiponectin plays a role in preventing ectopic fat accumulation by enhancing the storage of lipids (Stern et al. 2016). Thus, any dysfunction in the receptors of adiponectin or the adiponectin expression level could affect both fat and glucose homeostasis. One of the essential proteins in the process of glucose uptake is the insulin-responsive glucose transporter (GLUT4) which is selectively expressed in AT and muscles (Stein and Litman 2015; Brodsky 2016). Induction of GLUT4 by insulin stimulates the glucose uptake; thus, the reduction of GLUT4 expression in AT alters its function and affects the insulin signaling which leads to impairment of glucose homeostasis (Olson 2012). It has been found that, under subacute $\mathrm{Cd}$ exposure, $\mathrm{Cd}$-treated rats showed a significant reduction in GLUT4 mRNA and GLUT4 Protien levels in adipocytes (Han et al. 2003). To investigate the adiponectin effects, dysfunctional 3T3-L1 adipocytes (with low expression level of AdipoR2, GLUT4, and high inflammation) was treated with adiponectin (Pandey et al. 2019). As a result, adiponectin treatment showed an advantageous effect in enhancing glucose homeostasis and reducing inflammation. This is mediated via the key signaling molecule of adiponectin signals transduction (APPL-1) that regulates AMPK phosphorylation (Pandey et al. 2019). Altogether, this reflects the importance and the beneficial role of adiponectin in the maintenance of glucose homeostasis and fat storage function.

\section{Cadmium and Leptin}

Leptin is one of the main adipokines that is expressed and secreted by AT with a molecular weight of $16 \mathrm{kDa}$ and is known for its pro-inflammatory properties (Myers 2003). The main functions of leptin include regulation of food intake, lipid metabolism, energy expenditure, and glucose homeostasis (Considine 2004; Martínez-Sánchez 2020). The concentration of circulating leptin is proportional to the AT size; it is linked with energy storage as well as nutritional status (Frederich et al. 1995; Considine et al. 1996; Martínez-Sánchez 2020). It has been found that in humans, the lipo-dystrophic phenotype is similar to the leptin-deficient phenotype (Oral et al. 2002). Moreover, the failed attempt of adipocytes transplantation from ob/ob mice (leptin-deficient) to a lipodystrophic strain of mice with aim of treating the metabolic disturbance; emphasized the critical role of ATderived leptin (Friedman 2002). In this context, the results of Kawakami et al. (2010, 2012, 2013) highlighted that Cd exposure induces a reduction in adipocyte size which is accompanied by a decrease in the expression level of leptin. Another study by Levy et al. (2000) reported that leptin expression level was reduced under the $\mathrm{Cd}$ exposure in a dose-dependent manner. However, the study did not evaluate the $\mathrm{Cd}$ effect on adipocyte histopathology. This promotes the hypothesis of $\mathrm{Cd}$ lipodystrophic effect on adipocytes, which requires continuous efforts to be studied.

In terms of leptin receptors, there are multiple isoforms that can be classified as short and long secreted isoforms (Myers and Greenwald-Yarnell 2013). The long isoform $(\mathrm{ObRb})$ is a fully active receptor attributed to the presence of the binding domains that are required for the main signaling pathway (JAK/STAT) of leptin (Harris 2014). It has been found that mice with ObRb deficiency exhibited similar phenotypes of leptin-deficient mice as well as mice that lacked all short isoforms (Myers and Greenwald-Yarnell 2013). 
This indicates the important role of ObRb in leptin activities. The target sites of leptin action are mainly in the central nervous system, then in lower expression level in the peripheral tissues including AT (Wrann and Rosen 2012; MartínezSánchez 2020). All isoforms of leptin receptors have been demonstrated in AT and their location was found to be in the cell membrane and the cytoplasmic vesicle (MartínezSánchez 2020). The direct effect of leptin on AT was confirmed in 1997 when adipocytes were treated with leptin through the activation of the JAK/STAT pathway (SiegristKaiser et al. 1997). Also, leptin receptors were found to be in all AT components, such as macrophage and endothelial cells, which suggests autocrine and paracrine actions for leptin besides its primary endocrine action (Bornstein et al. 2000; Martínez-Sánchez 2020). Another vital process that involves leptin is glucose homeostasis. In the case of insulin increment, leptin secretion is stimulated from AT to regulate insulin levels. The disturbance of this insulin regulation process by leptin contributes to developing insulin resistance which leads to diabetes mellitus (Inui et al. 2012). Under chronic Cd treatment, it has been reported that the insulin receptors of adipocytes exhibited significant reduction compared to the control (Ficková et al. 2003). This could be linked with the similar effect of $\mathrm{Cd}$ on leptin secretion which may be associated with the induction of AT-insulin resistance. Although the above-listed data show the adverse impact of $\mathrm{Cd}$ on adipocyte function that is related to leptin activity, yet more studies are required to provide a clear and better understanding.

\section{Cadmium and Adipose Tissue Macrophages (ATMs)}

As mentioned earlier, AT is not only composed of adipocytes but also contains endothelial cells, fibroblasts, and immune cells, which contribute to AT homeostasis. ATMs are the most abundant type of immune cells in AT that maintains homeostasis by clearing the dead adipocytes in healthy conditions (Catrysse and van Loo 2018). Another function of ATMs is lipid buffering during lipolysis. They get recruited to the AT and exhibit an anti-inflammatory phenotype (M2) to uptake the released lipids; this prevents the increment of plasma FFA (Catrysse and van Loo 2018). Classically, macrophages are divided into M1 (pro-inflammatory) and M2 (anti-inflammatory) which have different markers, activators, and functions (Bai and Sun 2015). Cytokines released and produced by M1 are TNF- $\alpha$, IL- 6 , IL-12, IL-23, and IL- $1 \beta$ while M2 produces IL- 10 , IL- 4 , and TGF- $\beta$ cytokines (Li et al. 2020). Normally, the exhibited phenotype of resident macrophages is M2 macrophages and it expresses M2 markers (Chait and den Hartigh 2020). It has been reported that the shift of macrophages' phenotype from M2 to M1 is induced by MCP-1 that recruits the inflammatory cells ( $\mathrm{Li}$ et al. 2020). In the situation of AT macrophage infiltration,
TNF- $\alpha$ and IL-6 are mostly produced (Guzik et al. 2017). These pro-inflammatory cytokines were found to be upregulated by $\mathrm{Cd}$ while the anti-inflammatory cytokine IL-10 is significantly downregulated by Cd (Salama et al. 2019). These cytokines are known to activate nuclear factor kappa $\mathrm{B}(\mathrm{NF}-\mathrm{\kappa B})$ signaling which activates the transcription of proteins and inflammatory factors that are involved in inflammatory pathways (Matafome and Seiça 2017). A study by Freitas \& Fernandes (2011) found that Cd significantly activated NF- $\mathrm{KB}$ signaling as well as the induction of TNF$\alpha$, and IL- 6 releasing in monocytes.

Another function of ATMs is the production of adipokine known as resistin. It has a molecular weight of $12.5 \mathrm{kDa}$ and has a pro-inflammatory effect (Kyrou et al. 2017). Recently, its receptor in humans has been identified to be CAP1 which mediates its pro-inflammatory effect (Lee et al. 2014). These effects include activation of NF- $\kappa \mathrm{B}$ and inhibition of AMPK signaling which leads to impairment of insulin homeostasis (Farkhondeh et al. 2020). Moreover, it has been reported that resistin upregulates MCP-1 expression (Fantuzzi 2005) as well as increases the expression level of TNF- $\alpha$ and IL-6 (Kyrou et al. 2017). In terms of lipid storage, a fundamental function of AT, TNF- $\alpha$ was found to suppress PPAR $\gamma$ activity which causes downregulation of the main enzymes involved in esterification and fatty acid uptake and decreased expression level of adiponectin (Mancuso 2016; Matafome and Seiça 2017). Collectively, the reports cited above indicate the pro-inflammatory effects of macrophages shifted phenotype (M1) on adipokine secretion and AT dysfunction. A recent in vitro study exploring the effect of $\mathrm{Cd}$ on macrophages and mast cells reported that in a time-dependent manner the secretion level of TNF- $\alpha$ was significantly increased in Cd-treated cells (García-Mendoza et al. 2019). Moreover, $\mathrm{Cd}$ was found to downregulate the anti-inflammatory adipokine, IL-10, at both mRNA and protein levels (Choudhury et al. 2021). These studies represent the investigation of Cd effects based on the secretion pattern of adipocytokines that is related to or produced by ATMs and used as markers for its function. Nevertheless, few studies explored the Cd effect on ATMs specifically. Thus, more histopathological, metabolic, and molecular studies are required to get a better understanding of Cd direct impact on ATMs. This is important since the ATMs activation state and metabolic phenotype are related to inflammation development and metabolic disorders.

\section{Cadmium and Dysfunctional AT Signaling}

Critical processes such as lipolysis and lipogenesis were found to be adversely affected by $\mathrm{Cd}$ exposure. As mentioned, these processes are dependent on hormonal, nutritional, and metabolic factors. This includes insulin, food 
intake, and both glucose and FFA circulating levels as main factors. AT responds to the systemic signals in fed condition to start lipogenesis. Under Cd exposure, the whole circulating lipid profile is changing since the levels of FFAs, TGs, LDL, VLDL is increasing while HDL is decreasing (Olisekodiaka et al. 2012; Treviño et al. 2015). After food intake, the glucose level is increasing which stimulates the production of insulin. When insulin is produced, it activates the GLUT4 in AT to uptake the glucose. However, Cd reduces the expression of GLUT4 which consequently impairs glucose uptake.

Another important function for the activated insulin is the stimulation of leptin production. As reported, Cd reduces leptin expression despite the increases in insulin production. This could be explained by the reduction of insulin receptors in AT (Ficková et al. 2003) which impairs the insulin signaling with AT and adversely affects the production of leptin. According to the mathematical homeostasis model assessment (HOMA-IR), insulin resistance is highly elevated in the case of $\mathrm{Cd}$ exposure in peripheral tissues (Treviño et al. 2015). This is consistent with the results of the insulin resistance adipocytes dysfunction index (IDA-IR) that reported a significant increment of insulin resistance for Cd-treated AT (Treviño et al. 2015). Similarly, a recent study found that elevated Cd level in AT of smoker participants is positively related to the increased level of both HOMA-IR and insulin (Salcedo-Bellido et al. 2021). Although adiponectin is produced by AT and is known to have insulin-sensitizing action as well as facilitate fatty acid oxidation, its expression is downregulated by $\mathrm{Cd}$. As a result, its contribution to reduce insulin resistance or facilitate the oxidation of fatty acids is limited. Also, insulin activates LPL to facilitate the process of FFAs uptake from circulation to be converted into TGs in AT. However, due to the impairment of glucose uptake, the amount of glycerol becomes insufficient for the FFAs esterification.

In the fasting state, AT responds to the systemic demand for energy and releases TGs as FFAs and glycerol. This is done through the protein kinase A which stimulates HSL activation and perilipin phosphorylation. Perilipin is a critical protein that coats lipid droplets and prevents TGs hydrolysis (Sztalryd and Brasaemle 2017). Once perilipin is phosphorylated, adipose triglyceride lipase (ATGL) is activated and releases both FFAs and glycerol. In the case of $\mathrm{Cd}$ exposure, perilipin expression is downregulated which means the gatekeeper of TGs is dysfunctional (Kawakami et al. 2013). Subsequently, the unhealthy storage will be reflected by the increment of FFAs in the circulation and plasma lipid profile alteration.

Furthermore, both PPAR- $\gamma$ and C/EBP- $\alpha$ are key regulators of AT vital processes. For example, $\mathrm{C} / \mathrm{EBP} \alpha$ was found to be involved in the transactivation of GLUT4 promotor and insulin receptors (White and Stephens 2010). Also, it is a transcriptional activator of leptin promotor (Kang et al. 2014; van der Krieken et al. 2015). Moreover, PPAR- $\gamma$ is known as a regulator of genes involved in the lipoproteins metabolism (Tyagi et al. 2011). Also, it has a direct effect on the modulation of HSL transcription (White and Stephens 2010). Additionally, it has a role in the induction of adiponectin in adipocytes and promoting insulin sensitivity (Akingbemi 2013). These roles can be impaired in the case of $\mathrm{Cd}$ exposure since its disruptive effect on their expression level has been confirmed.

To summarize what has been stated (Fig. 3), Cd affects the main functions of AT which is lipid homeostasis followed by adipokines secretion. Disrupting both lipogenesis and lipolysis induces metabolic dysfunction as well as signaling impairment. As a consequence, systemic homeostasis undergoes deficiency and the risk of developing the metabolic disorder is highly likely to occur.

\section{Conclusion}

Despite the evidence from research that suggests toxic effects of $\mathrm{Cd}$ on biological activities, the area of $\mathrm{Cd}$ impact on AT is not well explored yet. Adipose tissue has a vital role in the maintenance of systemic homeostasis and metabolic flow. Indicators of a functional AT are lipid storage and adipokines secretion, and $\mathrm{Cd}$ adversely affects these two functions. Several factors contribute to the Cd-induced effects such as the exposure duration, exposure dose, tissue status, and body responses, which make the study of $\mathrm{Cd}$ challenging. Also, AT heterogeneity makes the response to $\mathrm{Cd}$ vary from one depot to another. However, the risk of AT dysfunction is high since it leads to metabolic alterations and consequently metabolic-related diseases. Thus, forthcoming studies are needed to optimize realistic doses that are equivalent to the environmental exposure for both animals and humans.

In the scope of the available data, $\mathrm{Cd}$ was found to be accumulated in AT with a non-neglectable role in AT dysfunction. Induction of pathological changes by affecting AT size and the induction of metabolic disorder through impairment of adipokines secretions lead to disruption of insulin homeostasis as well as recruitment of macrophages. Further studies are required to focus on understanding the mechanisms involved in the process of $\mathrm{Cd}$ accumulation in AT that caused AT dysfunction. Understanding the complex matrix of AT components and their interaction with different physiological conditions has the potential for enhancing the tracking of health problems. Therefore, besides the optimization of $\mathrm{Cd}$ doses, future studies should be comprehensively designed to involve all fields from molecular, histopathology to physiology. This will help to provide reliable monitoring of Cd-related 


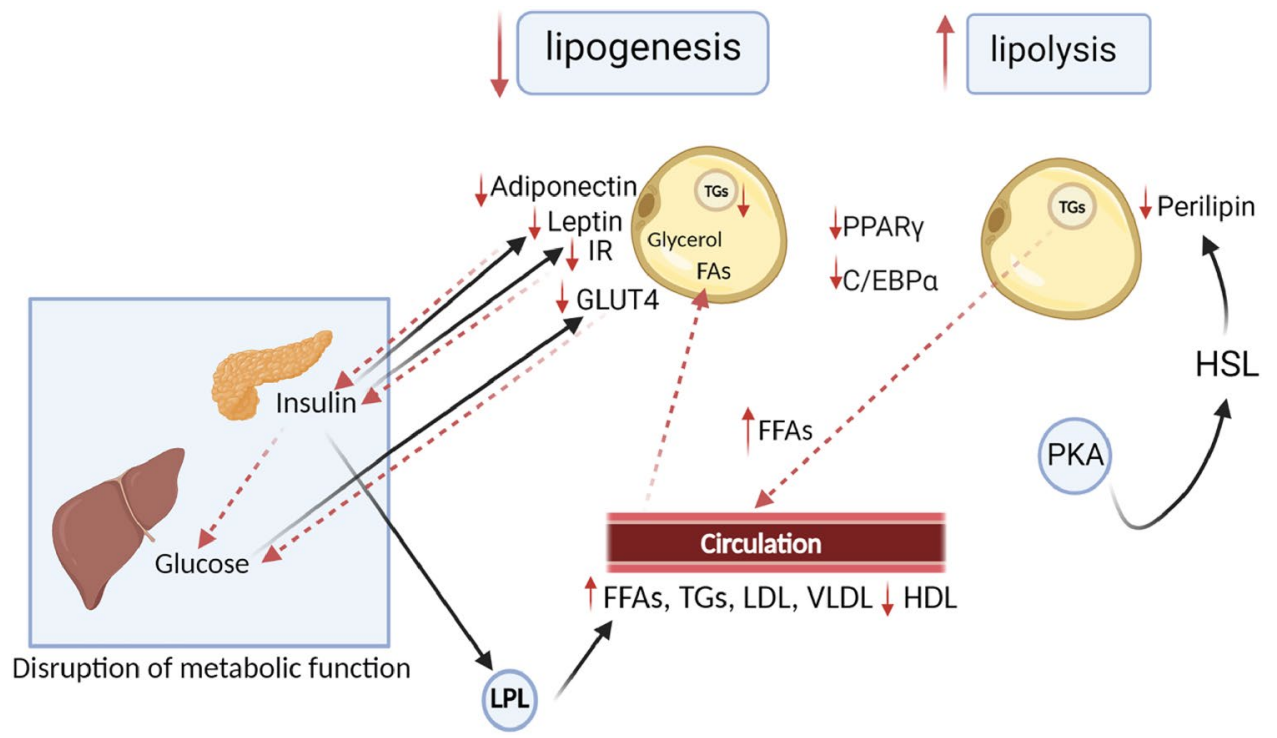

Fig. 3 Overview of Cd effect on dysfunctional AT signaling (Black arrows: processes under healthy physiological condition; Red dotted arrows: disruption of functional processes under $\mathrm{Cd}$ exposure condition). This graph illustrates the cross-talk signals of abnormal adipocytes. The main features of abnormal adipocyte due to $\mathrm{Cd}$ exposureis the declined expression of PPAR-y, C/EBP-alpha, leptin, GLUT4, perilipin, adiponectin and insulin receptor (IR) which are primarily produced and expressed in AT. Disruption of both PPAR-y and C/ EBP-alpha affects the expression level of adiponectin, leptin, IR, GLUT4 and the metabolism of lipoprotein lipase (LPL). An imbal-

effects and the degree of AT dysfunction can be confidently addressed. Unfortunately, Cd contamination can affect most living forms and easily transport through the food chain to affect a large variety of living organisms. Although there are efforts to limit $\mathrm{Cd}$ exposure, the toxicity of $\mathrm{Cd}$ is still remarkably dangerous. Hence, the knowledge presented and discussed in this review should provide a comprehensive account of $\mathrm{Cd}$ adverse impact on AT and more understanding of AT as a vital organ and its response towards Cd exposure.

Author contributions SA: Conceptualization, Data Curation, Writing_-Original Draft, Visualization. KV: Review, Editing, Formatting. MS: Review, Editing. SD: Editing. HAAN: Conceptualization, Data Curation, Writing_-Review \& Editing, Visualization, Supervision.

Funding Open Access funding provided by Qatar University.

\section{Declarations}

Conflict of interest The authors have no conflicts of interest to declare that are relevant to the content of this review. ance between lipolysis and lipogenesis is the main indicator of AT dysfunction. Due to the body demand, insulin is produced. Since both IR and GLUT4 expression is impaired by Cd, insulin signaling, and leptin production are impaired as well. Also, Cd impairs the glucose uptake by AT through the reduction of GLUT4 expression. This disrupts the glucose conversion into glycerol and consequently, the free fatty acids (FFAs) esterification. As a result, level of FFAs in circulation is high. Accordingly, this is disrupting the metabolic function related to insulin signaling. (Created using BioRender.com)

Open Access This article is licensed under a Creative Commons Attribution 4.0 International License, which permits use, sharing, adaptation, distribution and reproduction in any medium or format, as long as you give appropriate credit to the original author(s) and the source, provide a link to the Creative Commons licence, and indicate if changes were made. The images or other third party material in this article are included in the article's Creative Commons licence, unless indicated otherwise in a credit line to the material. If material is not included in the article's Creative Commons licence and your intended use is not permitted by statutory regulation or exceeds the permitted use, you will need to obtain permission directly from the copyright holder. To view a copy of this licence, visit http://creativecommons.org/licenses/by/4.0/.

\section{References}

Achari A, Jain S (2017) Adiponectin, a therapeutic target for obesity, diabetes, and endothelial dysfunction. Int J Mol Sci 18:1321. https://doi.org/10.3390/ijms18061321

Afolabi OK, Oyewo EB, Adekunle AS et al (2012) Original article: impaired lipid levels and inflammatory response in rats exposed to cadmium. EXCLI J 11:677-687

Akingbemi BT (2013) Adiponectin receptors in energy homeostasis and obesity pathogenesis. In: Tao Y-XBT-P in MB and TS (ed) $G$ protein-coupled receptors in energy homeostasis and obesity pathogenesis. Academic Press, New York, pp 317-342 
Ali H, Khan E, Ilahi I (2019) Environmental chemistry and ecotoxicology of hazardous heavy metals: environmental persistence, toxicity, and bioaccumulation. J Chem 2019:1-14. https://doi. org/10.1155/2019/6730305

ATSDR (2019) ATSDR's substance priority list. https://www.atsdr. cdc.gov/spl/\#

Badimon L, Cubedo J (2017) Adipose tissue depots and inflammation: effects on plasticity and resident mesenchymal stem cell function. Cardiovasc Res 113:1064-1073. https://doi.org/10. 1093/cvr/cvx096

Bai Y, Sun Q (2015) Macrophage recruitment in obese adipose tissue. Obes Rev 16:127-136. https://doi.org/10.1111/obr.12242

Baran A, Tarnawski M (2015) Assessment of heavy metals mobility and toxicity in contaminated sediments by sequential extraction and a battery of bioassays. Ecotoxicology 24:1279-1293. https://doi.org/10.1007/s10646-015-1499-4

Bhunia P (2017) Environmental toxicants and hazardous contaminants: recent advances in technologies for sustainable development. $\mathrm{J}$ Hazardous, Toxic, Radioact Waste 21:02017001. https://doi.org/ 10.1061/(ASCE)HZ.2153-5515.0000366

Booth A, Magnuson A, Fouts J, Foster MT (2016) Adipose tissue: an endocrine organ playing a role in metabolic regulation. Horm Mol Biol Clin Investig 26:25-42. https://doi.org/10.1515/ hmbci-2015-0073

Bornstein SR, Abu-Asab M, Glasow A et al (2000) Immunohistochemical and ultrastructural localization of leptin and leptin receptor in human white adipose tissue and differentiating human adipose cells in primary culture. Diabetes 49:532-538. https://doi.org/10. 2337/diabetes.49.4.532

Borowska S, Brzóska M, Gałażyn-Sidorczuk M, Rogalska J (2017) Effect of an extract from Aronia melanocarpa L. berries on the body status of zinc and copper under chronic exposure to cadmium: an in vivo experimental study. Nutrients 9:1374. https:// doi.org/10.3390/nu9121374

Brasier AR (2010) The nuclear factor- B-interleukin-6 signalling pathway mediating vascular inflammation. Cardiovasc Res 86:211218. https://doi.org/10.1093/cvr/cvq076

Brodsky FM (2016) Clathrin and clathrin-dependent endocytosis. In: Bradshaw RA, Stahl PDBT-E of CB (eds) Encyclopedia of cell biology. Elsevier, Waltham, pp 384-393

Buha A, Đukić-Ćosić D, Ćurčić M et al (2020) Emerging links between cadmium exposure and insulin resistance: human, animal, and cell study data. Toxics 8:63. https://doi.org/10.3390/toxics8030 063

Catrysse L, van Loo G (2018) Adipose tissue macrophages and their polarization in health and obesity. Cell Immunol 330:114-119. https://doi.org/10.1016/j.cellimm.2018.03.001

Ceddia RB, Somwar R, Maida A et al (2005) Globular adiponectin increases glut 4 translocation and glucose uptake but reduces glycogen synthesis in rat skeletal muscle cells. Diabetologia 48:132-139. https://doi.org/10.1007/s00125-004-1609-y

Ceja-Galicia ZA, Daniel A, Salazar AM et al (2017) Effects of arsenic on adipocyte metabolism: is arsenic an obesogen? Mol Cell Endocrinol 452:25-32. https://doi.org/10.1016/j.mce.2017.05. 008

Chait A, den Hartigh LJ (2020) Adipose tissue distribution, inflammation and its metabolic consequences, including diabetes and cardiovascular disease. Front Cardiovasc Med. https://doi.org/ 10.3389/fcvm.2020.00022

Choe SS, Huh JY, Hwang IJ et al (2016) Adipose tissue remodeling: its role in energy metabolism and metabolic disorders. Front Endocrinol (lausanne) 7:1-16. https://doi.org/10.3389/fendo. 2016.00030

Choudhury C, Mazumder R, Biswas R, Sengupta M (2021) Cadmium exposure induces inflammation through the canonical NF- $\mathrm{KB}$ pathway in monocytes/macrophages of Channa punctatus Bloch. Fish Shellfish Immunol 110:116-126. https://doi.org/10.1016/j. fsi.2021.01.002

Chunhabundit R (2016) Cadmium exposure and potential health risk from foods in contaminated area, Thailand. Toxicol Res 32:6572. https://doi.org/10.5487/TR.2016.32.1.065

Cimboláková I, Uher I, Veszelits Laktičová K, et al (2020) Heavy metals and the environment. In: Environmental factors affecting human health. IntechOpen, p 13

Coelho M, Oliveira T, Fernandes R (2013) Biochemistry of adipose tissue: an endocrine organ. Arch Med Sci 2:191-200. https://doi. org/10.5114/aoms.2013.33181

Considine R V (2004) Leptin. In: Martini LBT-E of ED (ed) Encyclopedia of endocrine diseases. Elsevier, New York, pp 164-170

Considine RV, Sinha MK, Heiman ML et al (1996) Serum immunoreactive-leptin concentrations in normal-weight and obese humans. N Engl J Med 334:292-295. https://doi.org/10.1056/NEJM1 99602013340503

COWI A/S (2003) Nordic council of ministers cadmium review. 26

Dallinger R, Prosi F, Segner H, Back H (1987) Contaminated food and uptake of heavy metals by fish: a review and a proposal for further research. Oecologia 73:91-98. https://doi.org/10.1007/ BF00376982

Echeverría R, Vrhovnik P, Salcedo-Bellido I et al (2019) Levels and determinants of adipose tissue cadmium concentrations in an adult cohort from Southern Spain. Sci Total Environ 670:10281036. https://doi.org/10.1016/j.scitotenv.2019.03.114

Egger AE, Grabmann G, Gollmann-Tepeköylü C et al (2019) Chemical imaging and assessment of cadmium distribution in the human body. Metallomics 11:2010-2019. https://doi.org/10.1039/ C9MT00178F

Fantuzzi G (2005) Adipose tissue, adipokines, and inflammation. J Allergy Clin Immunol 115:911-919. https://doi.org/10.1016/j. jaci.2005.02.023

Fantuzzi G, Braunschweig C (2014) Adipose tissue and adipokines in health and disease. Humana Press, Totowa, NJ

Farkhondeh T, Samarghandian S, Azimi-Nezhad M (2019) The role of arsenic in obesity and diabetes. J Cell Physiol 234:12516-12529. https://doi.org/10.1002/jcp. 28112

Farkhondeh T, Llorens S, Pourbagher-Shahri AM et al (2020) An overview of the role of adipokines in cardiometabolic diseases. Molecules 25:5218. https://doi.org/10.3390/molecules25215218

Fasshauer M, Blüher M (2015) Adipokines in health and disease. Trends Pharmacol Sci 36:461-470. https://doi.org/10.1016/j. tips.2015.04.014

Fatima G, Raza AM, Hadi N et al (2019) Cadmium in human diseases: it's more than just a mere metal. Indian J Clin Biochem 34:371378. https://doi.org/10.1007/s12291-019-00839-8

Fay M, Alt L, Ryba D et al (2018) Cadmium nephrotoxicity is associated with altered MicroRNA expression in the rat renal cortex. Toxics 6:16. https://doi.org/10.3390/toxics6010016

Ficková M, Eybl V, Kotyzová D et al (2003) Long lasting cadmium intake is associated with reduction of insulin receptors in rat adipocytes. Biometals 16:561-566. https://doi.org/10.1023/a: 1023485130767

Francisco V, Pérez T, Pino J et al (2017) Biomechanics, obesity, and osteoarthritis. The role of adipokines: when the levee breaks. J Orthop Res 36:594-604. https://doi.org/10.1002/jor.23788

Frederich RC, Hamann A, Anderson S et al (1995) Leptin levels reflect body lipid content in mice: evidence for diet-induced resistance to Leptin action. Nat Med 1:1311-1314. https://doi.org/10.1038/ nm1295-1311

Freitas M, Fernandes E (2011) Zinc, cadmium and nickel increase the activation of NF- $\mathrm{KB}$ and the release of cytokines from THP-1 
monocytic cells. Metallomics 3:1238. https://doi.org/10.1039/ c1mt00050k

Freitas Lima LC, de Braga VA, do Socorro de França Silva M, et al (2015) Adipokines, diabetes and atherosclerosis: an inflammatory association. Front Physiol. https://doi.org/10.3389/fphys. 2015.00304

Friedman J (2002) Fat in all the wrong places. Nature 415:268-269. https://doi.org/10.1038/415268a

Frühbeck G, Gómez-Ambrosi J (2013) Adipose tissue: structure, function and metabolism. In: Encyclopedia of human nutrition. Elsevier, New York, pp 1-13

Frühbeck G, Catalán V, Rodríguez A et al (2017) Involvement of the Leptin-adiponectin axis in inflammation and oxidative stress in the metabolic syndrome. Sci Rep 7:6619. https://doi.org/10.1038/ s41598-017-06997-0

Funahashi T, Shimomura I, Matsuzawa Y (2004) Adipocytokines. In: Martini LBT-E of ED (ed) Encyclopedia of endocrine diseases. Elsevier, New York, pp 41-44

Gao Y, Liu J, Bai Z et al (2019) Iron down-regulates leptin by suppressing protein $\mathrm{O}-\mathrm{GlcNAc}$ modification in adipocytes, resulting in decreased levels of O-glycosylated CREB. J Biol Chem 294:5487-5495. https://doi.org/10.1074/jbc.RA118.005183

Garcia-Morales P, Saceda M, Kenney N et al (1994) Effect of cadmium on estrogen receptor levels and estrogen-induced responses in human breast cancer cells. J Biol Chem 269:16896-16901. https://doi.org/10.1016/S0021-9258(19)89474-7

García-Mendoza D, Han B, Berg HJHJ, Brink NW (2019) Cell-specific immune-modulation of cadmium on murine macrophages and mast cell lines in vitro. J Appl Toxicol 39:992-1001. https://doi. org/10.1002/jat.3788

Genchi G, Sinicropi MS, Lauria G et al (2020) The effects of cadmium toxicity. Int J Environ Res Public Health 17:3782. https://doi.org/ 10.3390/ijerph17113782

Greevenbroek MMJ, Schalkwijk CG, Stehouwer CDA (2016) Dysfunctional adipose tissue and low-grade inflammation in the management of the metabolic syndrome: current practices and future advances. F1000Research 5:2515. https://doi.org/10.12688/f1000 research.8971.1

Guzik TJ, Skiba DS, Touyz RM, Harrison DG (2017) The role of infiltrating immune cells in dysfunctional adipose tissue. Cardiovasc Res 113:1009-1023. https://doi.org/10.1093/cvr/cvx108

Han JC, Park SY, Hah BG et al (2003) Cadmium induces impaired glucose tolerance in rat by down-regulating GLUT4 expression in adipocytes. Arch Biochem Biophys 413:213-220. https://doi. org/10.1016/S0003-9861(03)00120-6

Han S, Ha K, Jeon J et al (2015) Impact of cadmium exposure on the association between lipopolysaccharide and metabolic syndrome. Int J Environ Res Public Health 12:11396-11409. https://doi.org/ 10.3390/ijerph120911396

Harris RBS (2014) Direct and indirect effects of leptin on adipocyte metabolism. Biochim Biophys Acta - Mol Basis Dis 1842:414423. https://doi.org/10.1016/j.bbadis.2013.05.009

Henriques F, H. Bedard A, Luiz Batista Júnior M (2019) Adipose tissue inflammation and metabolic disorders. In: Adipose tissue - an update. Intechopen, p 13

Hossein-Khannazer N, Azizi G, Eslami S et al (2020) The effects of cadmium exposure in the induction of inflammation. Immunopharmacol Immunotoxicol 42:1-8. https://doi.org/10.1080/08923 973.2019.1697284

Iavicoli I, Fontana L, Bergamaschi A (2009) The effects of metals as endocrine disruptors. J Toxicol Environ Heal Part B 12:206-223. https://doi.org/10.1080/10937400902902062

Inui A, Tsai M, Amitani H, Asakawa A (2012) Stimulation of leptin secretion by insulin. Indian J Endocrinol Metab 16:543. https:// doi.org/10.4103/2230-8210.105570
Jacobo-Estrada T, Santoyo-Sánchez M, Thévenod F, Barbier O (2017) Cadmium handling, toxicity and molecular targets involved during pregnancy: lessons from experimental models. Int J Mol Sci 18:1590. https://doi.org/10.3390/ijms 18071590

Jiménez-Ortega V, Cano Barquilla P, Fernández-Mateos P et al (2012) Cadmium as an endocrine disruptor: correlation with anterior pituitary redox and circadian clock mechanisms and prevention by melatonin. Free Radic Biol Med 53:2287-2297. https://doi. org/10.1016/j.freeradbiomed.2012.10.533

Kahn CR, Wang G, Lee KY (2019) Altered adipose tissue and adipocyte function in the pathogenesis of metabolic syndrome. J Clin Invest 129:3990-4000. https://doi.org/10.1172/JCI129187

Kang X, Xie Q-Y, Zhou J-S et al (2014) C/EBP- $\alpha$, involvement of a novel transcription factor in leptin-induced VCAM-1 production in mouse chondrocytes. FEBS Lett 588:1122-1127. https://doi. org/10.1016/j.febslet.2014.02.032

Kawakami T, Sugimoto H, Furuichi R et al (2010) Cadmium reduces adipocyte size and expression levels of adiponectin and Peg1/ Mest in adipose tissue. Toxicology 267:20-26. https://doi.org/ 10.1016/j.tox.2009.07.022

Kawakami T, Nishiyama K, Tanaka J, et al (2012) Changes in macrophage migration and adipokine gene expression induced by cadmium in white adipose tissue of metallothionein-null mice. In: Annual Meeting of the Japanese Society of Toxicology. p AP-46

Kawakami T, Nishiyama K, Kadota Y et al (2013) Cadmium modulates adipocyte functions in metallothionein-null mice. Toxicol Appl Pharmacol 272:625-636. https://doi.org/10.1016/j.taap. 2013.07.015

Kay SH (1985) Cadmium in aquatic food webs BT-residue reviews. Springer, New York, pp 13-43

Kim K, Melough M, Vance T et al (2018) Dietary cadmium intake and sources in the US. Nutrients 11:2. https://doi.org/10.3390/ nu11010002

Krakoff J, Funahashi T, Stehouwer CDA et al (2003) Inflammatory markers, adiponectin, and risk of type 2 diabetes in the Pima Indian. Diabetes Care 26:1745-1751. https://doi.org/10.2337/ diacare.26.6.1745

Kwon H, Pessin JE (2013) Adipokines mediate inflammation and insulin resistance. Front Endocrinol (lausanne) 4:71. https:// doi.org/10.3389/fendo.2013.00071

Kyrou I, Mattu HS, Chatha K, Randeva HS (2017) Fat Hormones, Adipokines. In: Schisler JC, Lang CH, Willis MSBT-E of the $\mathrm{H}$ in $\mathrm{H}$ and $\mathrm{D}$ (eds) Endocrinology of the heart in health and disease. Elsevier, New York, pp 167-205

Lauretta R, Sansone A, Sansone M et al (2019) Endocrine disrupting chemicals: effects on endocrine glands. Front Endocrinol (lausanne) 10:1-7. https://doi.org/10.3389/fendo.2019.00178

Lech T, Sadlik JK (2017) Cadmium concentration in human autopsy tissues. Biol Trace Elem Res 179:172-177. https://doi.org/10. 1007/s12011-017-0959-5

Lee EJ, Moon JY, Yoo BS (2012) Cadmium inhibits the differentiation of 3T3-L1 preadipocyte through the C/EBP $\alpha$ and PPAR $\gamma$ pathways. Drug Chem Toxicol 35:225-231. https://doi.org/10. 3109/01480545.2011.591401

Lee S, Lee H-C, Kwon Y-W et al (2014) Adenylyl cyclase-associated protein 1 is a receptor for human resistin and mediates inflammatory actions of human monocytes. Cell Metab 19:484-497. https://doi.org/10.1016/j.cmet.2014.01.013

Levy JR, Gyarmati J, Lesko JM et al (2000) Dual regulation of leptin secretion: intracellular energy and calcium dependence of regulated pathway. Am J Physiol Metab 278:E892-E901. https:// doi.org/10.1152/ajpendo.2000.278.5.E892

Li Y, Yun K, Mu R (2020) A review on the biology and properties of adipose tissue macrophages involved in adipose tissue 
physiological and pathophysiological processes. Lipids Health Dis 19:164. https://doi.org/10.1186/s12944-020-01342-3

Liu T, Zhang L, Joo D, Sun S-C (2017) NF-кB signaling in inflammation. Signal Transduct Target Ther 2:17023. https://doi.org/ 10.1038/sigtrans.2017.23

Luo C, Routh J, Dario M et al (2020) Distribution and mobilization of heavy metals at an acid mine drainage affected region in south china, a post-remediation study. Sci Total Environ 724:138122. https://doi.org/10.1016/j.scitotenv.2020.138122

Maeda N, Shimomura I, Kishida K et al (2002) Diet-induced insulin resistance in mice lacking adiponectin/ACRP30. Nat Med 8:731-737. https://doi.org/10.1038/nm724

Mancuso P (2016) The role of adipokines in chronic inflammation. ImmunoTargets Ther 5:47. https://doi.org/10.2147/ITT.S73223

Mandal P, Pratt BT, Barnes M et al (2011) Molecular mechanism for adiponectin-dependent M2 macrophage polarization. J Biol Chem 286:13460-13469. https://doi.org/10.1074/jbc.M110. 204644

Martínez-Fernández L, Fernández-Galilea M, Felix-Soriano E, et al (2018) Inflammation and oxidative stress in adipose tissue. In: del Moral AM, Aguilera García CMBT-O (eds) Obesity. Elsevier, New York, pp 63-92

Martínez-Sánchez N (2020) There and back again: leptin actions in white adipose tissue. Int J Mol Sci 21:6039. https://doi.org/10. 3390/ijms21176039

Matafome P, Seiça R (2017) Function and dysfunction of adipose tissue. In: Letra L, Seiça R (eds) Obesity and brain function. Springer, Cham, pp 3-31

Matović V, Buha A, Bulat Z, Đukić-Ćosić D (2011) Cadmium toxicity revisited: focus on oxidative stress induction and interactions with zinc and magnesium. Arch Ind Hyg Toxicol 62:65-76. https://doi.org/10.2478/10004-1254-62-2011-2075

Murdolo G, Piroddi M, Luchetti F et al (2013) Oxidative stress and lipid peroxidation by-roducts at the crossroad between adipose organ dysregulation and obesity-linked insulin resistance. Biochimie 95:585-594. https://doi.org/10.1016/j.biochi.2012.12.014

Mustieles V, Arrebola JP (2020) How polluted is your fat? What the study of adipose tissue can contribute to environmental epidemiology. J Epidemiol Community Health 74:401-407. https://doi. org/10.1136/jech-2019-213181

Myers MG (2003) Leptin. In: Henry HL, Norman AWBT-E of H (eds) Encyclopedia of hormones. Elsevier, New York, pp 563-572

Myers MG, Greenwald-Yarnell M (2013) Leptin. In: Second E (ed) Kastin AJBT-H of BAP. Handbook of biologically active peptides Elsevier, Boston, pp 1129-1134

Nasiadek M, Danilewicz M, Sitarek K et al (2018) The effect of repeated cadmium oral exposure on the level of sex hormones, estrous cyclicity, and endometrium morphometry in female rats. Environ Sci Pollut Res 25:28025-28038. https://doi.org/10.1007/ s11356-018-2821-5

Novotny D, Vaverkova H, Karasek D (2012) Adiponectin: a perspective adipose tissue marker with antiinflammatory and antiaterogenic potencial. In: Lipoproteins - Role in Health and Diseases. InTech, p 13

Olisekodiaka MJ, Igbeneghu CA, Onuegbu AJ et al (2012) Lipid, lipoproteins, total antioxidant status and organ changes in rats administered high doses of cadmium chloride. Med Princ Pract 21:156-159. https://doi.org/10.1159/000333385

Olson AL (2012) Regulation of GLUT4 and insulin-dependent glucose flux. ISRN Mol Biol 2012:1-12. https://doi.org/10.5402/2012/ 856987

Oral EA, Simha V, Ruiz E et al (2002) Leptin-replacement therapy for lipodystrophy. N Engl J Med 346:570-578. https://doi.org/10. 1056/NEJMoa012437
Orsso CE, Colin-Ramirez E, Field CJ et al (2020) Adipose tissue development and expansion from the womb to adolescence: an overview. Nutrients 12:2735. https://doi.org/10.3390/nu12092735

Ouchi N, Parker JL, Lugus JJ, Walsh K (2011) Adipokines in inflammation and metabolic disease. Nat Rev Immunol 11:85-97. https:// doi.org/10.1038/nri2921

Pandey GK, Vadivel S, Raghavan S et al (2019) High molecular weight adiponectin reduces glucolipotoxicity-induced inflammation and improves lipid metabolism and insulin sensitivity via APPL1AMPK-GLUT4 regulation in 3T3-L1 adipocytes. Atherosclerosis 288:67-75. https://doi.org/10.1016/j.atherosclerosis.2019.07.011

Patrick L (2003) Toxic metals and antioxidants: Part II. The role of antioxidants in arsenic and cadmium toxicity. Altern. Med. Rev. 8

Pellegrinelli V, Carobbio S, Vidal-Puig A (2016) Adipose tissue plasticity: how fat depots respond differently to pathophysiological cues. Diabetologia 59:1075-1088. https://doi.org/10.1007/ s00125-016-3933-4

Planchart A, Green A, Hoyo C, Mattingly CJ (2018) Heavy metal exposure and metabolic syndrome: evidence from human and model system studies. Curr Environ Heal Reports 5:110-124. https:// doi.org/10.1007/s40572-018-0182-3

Prabhu R, Ribeiro M, Kajdacsy-Balla A (2020) The toxic effect of environmental cadmium on visceral adipose tissue. FASEB J 34:1-1. https://doi.org/10.1096/fasebj.2020.34.s1.06577

Prins JB (2002) Adipose tissue as an endocrine organ. Best Pract Res Clin Endocrinol Metab 16:639-651. https://doi.org/10.1053/ beem.2002.0222

Recinella L, Orlando G, Ferrante C et al (2020) Adipokines: new potential therapeutic target for obesity and metabolic, rheumatic, and cardiovascular diseases. Front Physiol. https://doi.org/10.3389/ fphys.2020.578966

Renu K, Madhyastha H, Madhyastha R et al (2018) Role of arsenic exposure in adipose tissue dysfunction and its possible implication in diabetes pathophysiology. Toxicol Lett 284:86-95. https:// doi.org/10.1016/j.toxlet.2017.11.032

Richard AJ, White U, Elks CM, Stephens JM (2000) Adipose tissue: physiology to metabolic dysfunction. Endotext (2020)

Rizzetti DA, Corrales P, Piagette JT et al (2019) Chronic mercury at low doses impairs white adipose tissue plasticity. Toxicology 418:41-50. https://doi.org/10.1016/j.tox.2019.02.013

Sabir S, Akash MSH, Fiayyaz F et al (2019) Role of cadmium and arsenic as endocrine disruptors in the metabolism of carbohydrates: inserting the association into perspectives. Biomed Pharmacother 114:108802. https://doi.org/10.1016/j.biopha.2019.108802

Safety C for F (2011) Cadmium in food. https://www.cfs.gov.hk/engli sh/programme/programme_rafs/programme_rafs_fc_02_04 html. Accessed 19 Jan 2021

Salama SA, Arab HH, Hassan MH et al (2019) Cadmium-induced hepatocellular injury: modulatory effects of $\gamma$-glutamyl cysteine on the biomarkers of inflammation, DNA damage, and apoptotic cell death. J Trace Elem Med Biol 52:74-82. https://doi.org/10. 1016/j.jtemb.2018.12.003

Salcedo-Bellido I, Gómez-Peña C, Pérez-Carrascosa FM et al (2021) Adipose tissue cadmium concentrations as a potential risk factor for insulin resistance and future type 2 diabetes mellitus in GraMo adult cohort. Sci Total Environ 780:146359. https://doi. org/10.1016/j.scitotenv.2021.146359

Schoettl T, Fischer IP, Ussar S (2018) Heterogeneity of adipose tissue in development and metabolic function. J Exp Biol. https://doi. org/10.1242/jeb. 162958

Sharma M, McClung JA, Abraham NG (2016) Adiponectin. In: translational research in coronary artery disease. Elsevier, New York, pp 33-42 
Siegrist-Kaiser CA, Pauli V, Juge-Aubry CE et al (1997) Direct effects of leptin on brown and white adipose tissue. J Clin Invest 100:2858-2864. https://doi.org/10.1172/JCI119834

Stansfield WE, Ranek M, Pendse A, et al (2014) The pathophysiology of cardiac hypertrophy and heart failure. In: Willis MS, Homeister JW, Stone JRBT-C and MP of CD (eds) Cellular and molecular pathobiology of cardiovascular disease. Elsevier, San Diego, pp 51-78

Stein WD, Litman T (2015) Carrier-mediated transport. In: Stein WD, Litman Carriers, and Pumps (2nd edn.) TBT-C (eds) Channels, Carriers, and Pumps. Elsevier, London, pp 131-178

Stern JH, Rutkowski JM, Scherer PE (2016) Adiponectin, leptin, and fatty acids in the maintenance of metabolic homeostasis through adipose tissue crosstalk. Cell Metab 23:770-784. https://doi.org/ 10.1016/j.cmet.2016.04.011

Sztalryd C, Brasaemle DL (2017) The perilipin family of lipid droplet proteins: gatekeepers of intracellular lipolysis. Biochim Biophys Acta 1862:1221-1232. https://doi.org/10.1016/j.bbalip.2017.07. 009

Tchounwou PB, Yedjou CG, Patlolla AK, Sutton DJ (2012) Heavy metal toxicity and the environment. In: Luch A (ed) Molecular, clinical and environmental toxicology. Springer, Basel, pp 133-164

Tinkov AA, Filippini T, Ajsuvakova OP et al (2017) The role of cadmium in obesity and diabetes. Sci Total Environ 601-602:741755. https://doi.org/10.1016/j.scitotenv.2017.05.224

Tinkov AA, Aschner M, Ke T, et al (2021) Adipotropic effects of heavy metals and their potential role in obesity. Fac Rev. https://doi.org/ $10.12703 / \mathrm{r} / 10-32$

Toman R, Golian J, Šiška B, Massányi P (2009) Cadmium and selenium in animal tissues and their interactions after an experimental administration to rats. Slovak J Anim Sci 115-118

Treviño S, Waalkes MP, Flores Hernández JA et al (2015) Chronic cadmium exposure in rats produces pancreatic impairment and insulin resistance in multiple peripheral tissues. Arch Biochem Biophys 583:27-35. https://doi.org/10.1016/j.abb.2015.07.010

Trim W, Thompson D, Turner J (2018) Adipose tissue dysfunction. In: Gellman M, Turner JR (eds) Encyclopedia of behavioral medicine. Springer, New York, pp 1-5

Tucker P (2011) What Is the Biological Fate of Cadmium in the Body?

Tumminia A, Vinciguerra F, Parisi M et al (2019) Adipose tissue, obesity and adiponectin: role in endocrine cancer risk. Int J Mol Sci 20:2863. https://doi.org/10.3390/ijms20122863

Tyagi S, Sharma S, Gupta P et al (2011) The peroxisome proliferatoractivated receptor: a family of nuclear receptors role in various diseases. J Adv Pharm Technol Res 2:236. https://doi.org/10. 4103/2231-4040.90879

Unamuno X, Gómez-Ambrosi J, Rodríguez A et al (2018) Adipokine dysregulation and adipose tissue inflammation in human obesity. Eur J Clin Invest 48:e12997. https://doi.org/10.1111/eci.12997

Upadhyaya S, Kadamkode V, Mahammed R et al (2014) Adiponectin and IL-6. Adipocyte 3:39-45. https://doi.org/10.4161/adip.26553

van der Krieken SE, Popeijus HE, Mensink RP, Plat J (2015) CCAAT/ enhancer binding protein $\beta$ in relation to ER stress, inflammation, and metabolic disturbances. Biomed Res Int 2015:1-13. https:// doi.org/10.1155/2015/324815

Vegiopoulos A, Rohm M, Herzig S (2017) Adipose tissue: between the extremes. EMBO J 36:1999-2017. https://doi.org/10.15252/ embj.201696206

Violante A, Cozzolino V, Perelomov L et al (2010) Mobility and bioavailability of heavy metals and metalloids in soil environments. J Soil Sci Plant Nutr. https://doi.org/10.4067/S0718-9516201000 0100005

Vishvanath L, Gupta RK (2019) Contribution of adipogenesis to healthy adipose tissue expansion in obesity. J Clin Invest 129:4022-4031. https://doi.org/10.1172/JCI129191

Wang X, Karvonen-Gutierrez CA, Mukherjee B et al (2021) Urinary metals and adipokines in midlife women: the study of Women's Health Across the Nation (SWAN). Environ Res 196:110426. https://doi.org/10.1016/j.envres.2020.110426

White UA, Stephens JM (2010) Transcriptional control of adipogenesis and fat cell gene expression. Adipose tissue in health and disease. Wiley, Weinheim, pp 1-20

White U, Stephens J (2011) The gp130 receptor cytokine family: regulators of adipocyte development and function. Curr Pharm Des. https://doi.org/10.2174/138161211795164202

Wrann CD, Rosen ED (2012) New insights into adipocyte-specific leptin gene expression. Adipocyte 1:168-172. https://doi.org/10. 4161/adip. 20574

Xie T, Wang M, Chen W, Uwizeyimana H (2019) Impacts of urbanization and landscape patterns on the accumulation of heavy metals in soils in residential areas in Beijing. J Soils Sediments 19:148158. https://doi.org/10.1007/s11368-018-2011-6

Yamauchi T, Nio Y, Maki T et al (2007) Targeted disruption of AdipoR1 and AdipoR2 causes abrogation of adiponectin binding and metabolic actions. Nat Med 13:332-339. https://doi.org/10. $1038 / \mathrm{nm} 1557$

Ye J (2008) Regulation of PPAR $\gamma$ function by TNF- $\alpha$. Biochem Biophys Res Commun 374:405-408. https://doi.org/10.1016/j.bbrc. 2008.07.068

Ye R, Scherer PE (2013) Adiponectin, driver or passenger on the road to insulin sensitivity? Mol Metab 2:133-141. https://doi.org/10. 1016/j.molmet.2013.04.001

Young JL, Yan X, Xu J et al (2019) Cadmium and high-fat diet disrupt renal, cardiac and hepatic essential metals. Sci Rep 9:14675. https://doi.org/10.1038/s41598-019-50771-3

Zhang H, Li L, Wang Y et al (2016) NF- $\mathrm{BB}$ signaling maintains the survival of cadmium-exposed human renal glomerular endothelial cells. Int J Mol Med 38:417-422. https://doi.org/10.3892/ ijmm.2016.2640

Zhang Y, Li Y, Zhang J et al (2021) Cadmium induced inflammation and apoptosis of porcine epididymis via activating RAF1/ MEK/ERK and NF- $\kappa \mathrm{B}$ pathways. Toxicol Appl Pharmacol 415:115449. https://doi.org/10.1016/j.taap.2021.115449

Publisher's Note Springer Nature remains neutral with regard to jurisdictional claims in published maps and institutional affiliations. 